\title{
Decreased expression of four memory genes in non-syndromic cryptorchid males.
}

\author{
F. Hadziselimovic ${ }^{1}$, N.O. Hadziselimovic ${ }^{1,2}$, \\ P. Demougin², E.J. Oakeley ${ }^{3}$ \\ 1. Institute of Andrology Liestal, \\ 2. Biozentrum University of Basel, and \\ 3. Novartis Institutes for Biomedical Research, Department of Molecular Biology, Basel, Switzerland
}

\section{Background:}

Egr1 has been widely recognized as essential for some aspects of learning and memory while Egr 4 has been shown to be involved in receptor - modulated memory processes.(1.2) Furthermore, it has been shown that testosterone enhances memory by increasing biological salience of incoming information.(3) In cryptorchid boys, an elevated odd ratio for low IQ was found. (4) It is postulated that the hypothalamus-pituitary-testicular axis is implicated in maintaining the similarity of gene expression between brain and the testis.

\section{Aim:}

We hypothesize that infertile cryptorchid males may have impaired expression of several memory genes in their testes.

\section{Patients and Methods:}

Whole genome analysis of testicular biopsies from 7 boys who underwent orchiopexy with typical testicular histology of a high risk infertility group[no Ad spermatogonia, total germ cell count $<0.2 /$ germ cell per tubule (HIR)] were compared to 12 biopsies of cryptorchid boys with low risk for developing infertility [Ad spermatogonia present and total germ cell count $>0.6 /$ germ cell per tubule (LIR)] utilizing Affymetrix microarrays and quantitative real time PCR and immunohistology.

\section{Results:}

The HIR group had low or lack of expression of the following memory genes compared to LIR: EGR1, EGR4, FMR2 and VCX3A. [Fig.

1.]Immunohistologic analysis revealed lower EGR1/EGR4 expression in the spermatogonia of the HIR group as compared to LIR testes.

\section{Figure 1.}

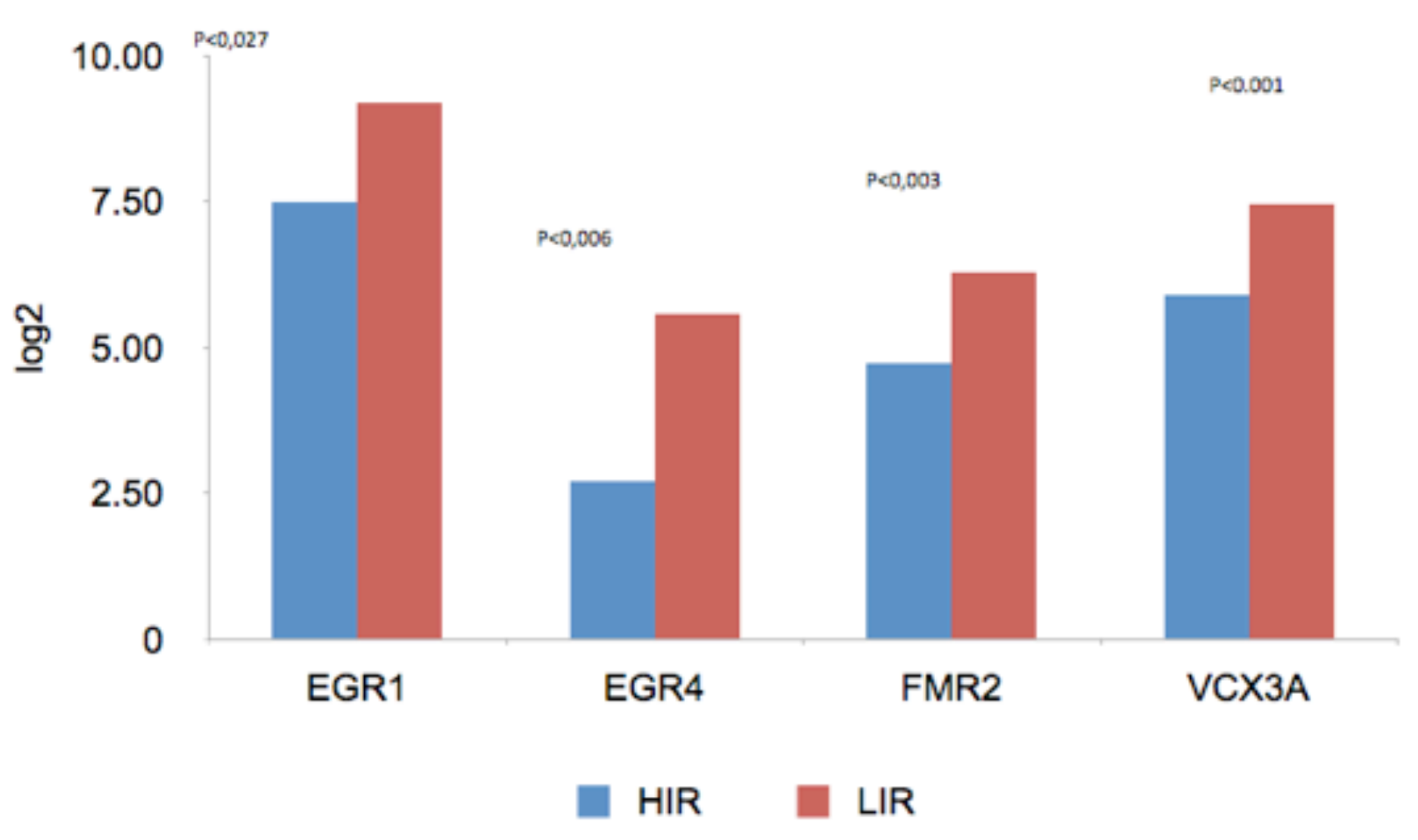

\section{Egr4 HIR}

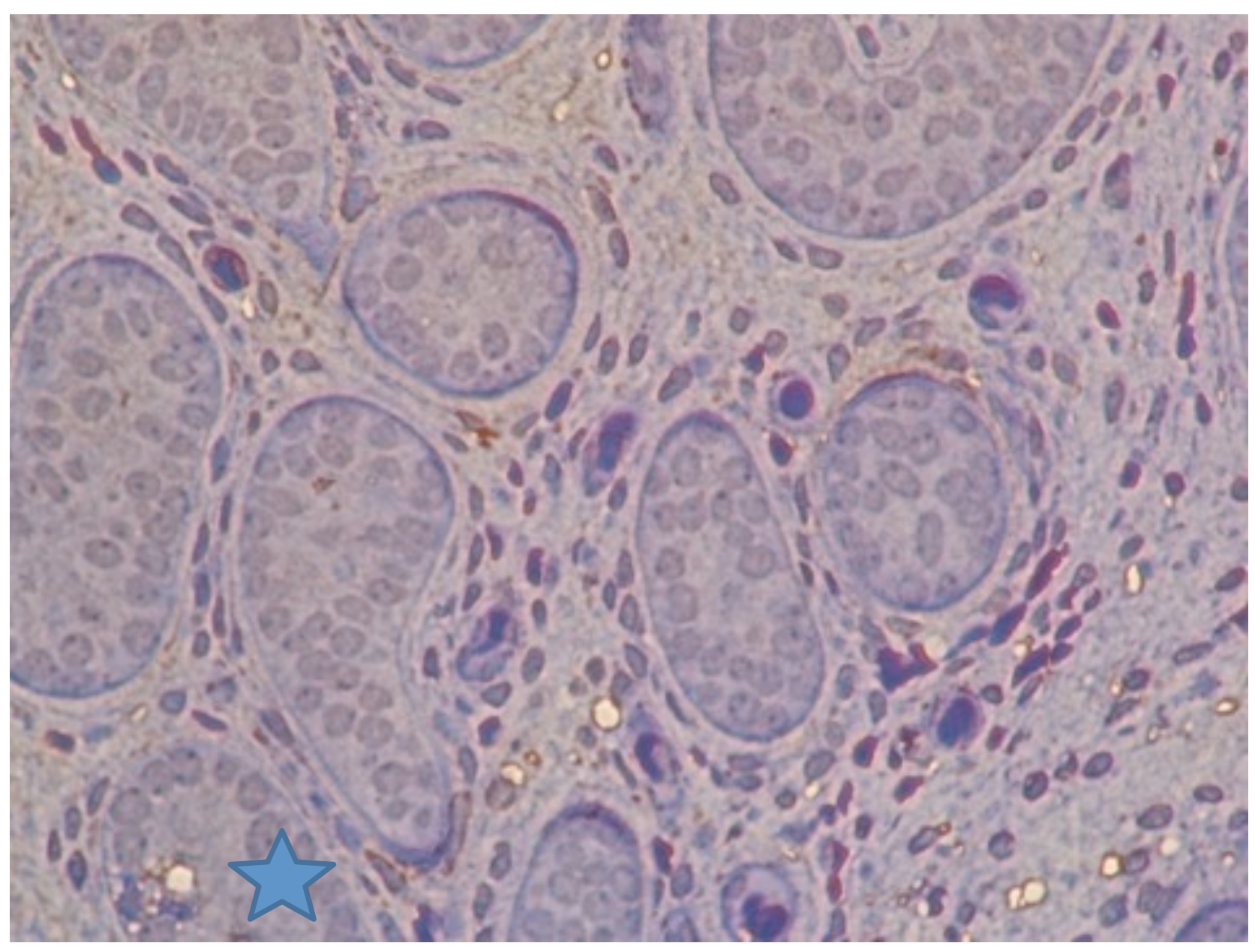

\section{Egr4 LIR}

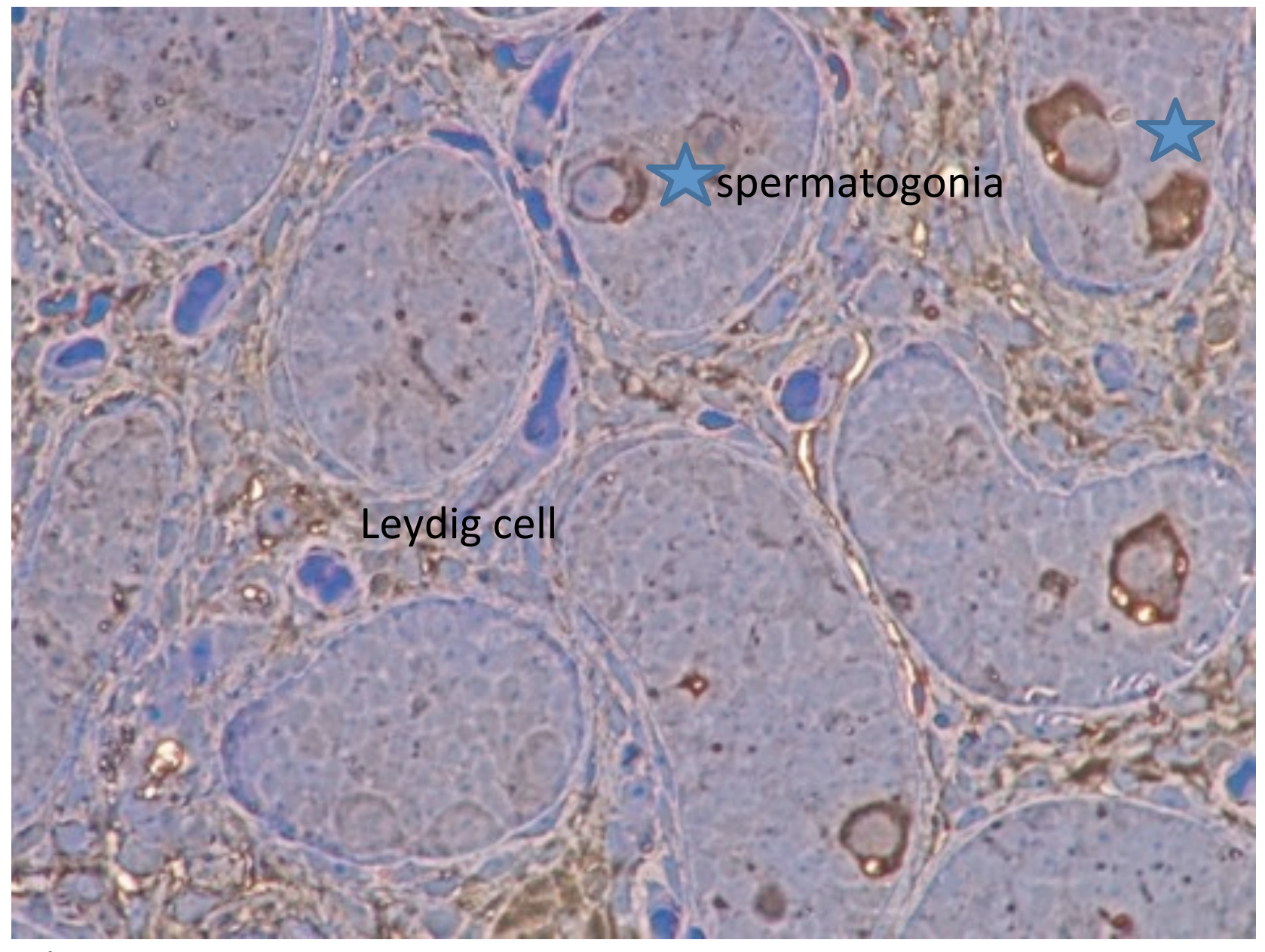

ț spermatogonia

\section{Conclusion:}

Impaired expression of four memory genes known to encode for proteins involved in signalling pathways regulating cytoskeleton organization, synaptic vesicle transport and establishment of connections between neuronal cells may contribute to reduced intellectual and cognitive functions of cryptorchid males. The current findings provide new insight into potential molecular mechanisms into crucial processes for the development of these functions.

\section{References:}

1. L. Li, J. Carter, X. Gao, J. Whitehead , W. G. Tourtellotte The NeuroplasticityAssociated Arc Gene a Direct Transcriptional Target of Early Growth Response (Egr) Transcription Factors Mol. Cell. Biol. 2005, 25(23):10286.

2. C. Li, S. Dong, H. Wang, Y. Hu Microarray Aanalysis of Gene Expression Changes in the Brains of NR2B-induced Memory-Enhanced Mice Neuroscience 197 (2011) 121-131

3. S. Ackermann, K. Spalek, B. Rasch, L. Gschwind, D. Coynel, M. Fastenrath, A. Papassotiropoulos, D. J.-F. de Quervain, Testosterone levels in healthy men are related to amygdala reactivity and memory performance Psychoneuroendocrinology (2012) 37, 1417-1424

4. Depue R. Cryptorchidism, an Epidemiologic Study with Emphasis on the Relationship to Central Nervous System Dysfunction Teratology 1988; 37:301 